Iraqi J. Vet. Med. 34 ( 2 ): 9 - 14; ( 2010 ).

\title{
Pathogenic effect of bunt wheat on male reproductive system in Mices.
}

\author{
Mustafa A.K. Al-Taie \\ University of Baghdad, College of Science, Biology Department
}

Accepted - September - 2010

\section{Summary}

This study was carried out to study the toxic effect of smut wheat on male reproductive system of mice. The experimental study was performed in the laboratory using 20 mice, which divided into two groups, one group feed on normal diet, the other fed on a mixture of $50 \%$ normal diet with $50 \%$ smut wheat. A histopathological study was done on the testes of Mice fed on smut wheat for 30 days. The histopathological study revealed thickness of basement membrane of semiriferous tubule of mice, and desquamation of the sertoli cells and spermatogonium from the basement membrane of seminiferous tubule and has adversely effect on male fertility.

Key words:buntwheat,malemices,reproductive.

$$
\begin{aligned}
& \text { التأثيرات الامراضية للحنطة المتفحمة على الجهاز التناسلي الأكري في الفئران. } \\
& \text { مصطفى عبد الخالق الطائي } \\
& \text { جامعة بغداد- كلية العلوم - قسم علوم الحياة }
\end{aligned}
$$

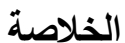

$$
\begin{aligned}
& \text { أستعلمت في هذه الدراسة } 20 \text { فارا قسمت الى مجموعتين , غذيت المجموعة الاولى على العليقة } \\
& \text { الاعنيادية , والمجموعة الثانية على عليقة حاوية 50\% حنطة متفحمة و 50\% عليقة اعنيادية ولمدة ثلاثون } \\
& \text { يومأ.أظهرت نتائج الدراسة النسيجية لخصى ذكور الفئران المتغذية على الحنطة المتفحمة حدوث تتكس في } \\
& \text { الخلايا المكون للنطف وتتخن في الغشاء القاعدي للانابيب الخصوية مع تهنك في الغشاء القاعدي للخلايا } \\
& \text { المغذية للمنطقة و هي تؤثز سلبا على خصوبة الذكور . }
\end{aligned}
$$

\section{Introduction}

Order ustilagenals, causes covered Kernal smut of cereals, it is considered as one of the most important pathogens on wheat and Barley and maize (1); The disease is quite common in southern and central parts of the country and responsible for losses each year (2),Very little work has been done on the toxic effect on man, poultry and other livestock animals (3), The serious disease caused by smuts which have been referred to us "ustilaginism", Debre and Nevot (4) had been described as an infantile disease similar to erythro - edema which may occur frequently in Central Europe in those infants fed on corn or bread containing spores of ustilago mydis, it is thought that consumption of ustilago. Smut of Tilletia carier Tilletia foetid (wallr.) Liro which belong to the same order ustilaginals have also been considered as toxic (5) ustilaginism, poisoning by smut spores which produces burning, itching, hyperemia, acrocyanosis and edema resemble ergotism, pellagra or infentile acrocynia (5and 6). It had been reported elsewhere that it provoke abortion in cattle and may cause contraction of uterine muscle and inhibit adrenaline. All the genera belong to same order have similar activities (7and 8). It was felt therefore that the histopathological study of female and male genetic systems of experimental animals fed on smut spore 
Iraqi J. Vet. Med. 34 ( 2 ): 9 - 14; ( 2010 ).

of Tilletia caries was needed and it was hoped that this work may stimulate other workers in this field in order to expose the effect of these toxins on animals and human.

\section{Materials and methods}

Thirty adult male albino mice were used in this study at the age of 10 weeks and weight 24 gram \pm 1 gram with optimum temperature incubation ranged between $22-25^{\circ} \mathrm{C}$ and fed on locally prepared diet. Tap water used as drinking water. Soft wood shaving used for bedding. 20 animals were divided into two groups, control group (T1) feed normal diet, and treated group (T2) fed on 50\% normal locally prepared diet mixed with $50 \%$ smut wheat infected with Tellitia caries provided from the Ministry of Trade for 30 days.

\section{Histopathological Study:}

Male reproductive organs were dissected out after one month of treatment. The organs were fixed in small containers containing $20 \mathrm{ml}$ of formalin $10 \%$ and dehydrated in progressively more concentrated alcohol, embedded in paraffin and cut into section 4-5 $\mu \mathrm{m}$ thickness stained with haematoxyline and eosin $(\mathrm{H} \& \mathrm{E})$ for microscopical examination (9and 10).

\section{Results and Discussion}

In the present study the result in the fig. 1 and 2 show the normal structure of the testis.In this study the appearance of thickness of basement membrane of seminiferos tubules due to fibroses .The fibroses enclosed the tubules and this lead to decrease in the number of spermatid Fig. 3and 4 may be due to the irritation by the trimethylamine and the destruction related to the polycyclic aromatic substance in the smut wheat. This results were in agreements with others $(6,11,12,13$ and14) who found that there was a toxic, carcinogenic material polycyclic aromatic hydrocarbon $(\mathrm{PAH})$, in addition to the trimethylamine which can cause irritation and damage of the living tissue in the body. This results showed the desquamation of the Sertoli cells and spermatogonium from the basement membrane, this spot the light on the irritative and destructive effect on male reproductive system which may lead consequently to infertility of male animals fed on smut wheat (15). and in some region completely degeneration were observed, this can be explained due to the irritation effect of the trimethylamine and polycyclic aromatic hydrocarbon (PAH) material in smut wheat $(12,13)$, Fig 5. some PAHs are carcinogens and may effect the male reproductive system (16 ).This result was disagree with the finding by (17) who state that the feeding of smut wheat for 45 days don't cause toxic effect in chicken. Despite the effect of all PAH metabolism in Mice adrenal gland, testis and overy, hormonally elevated in each tissue by a variety of possible mechanism including induction and selective proliferation of cells (18). According to the histopathological results, it is recommended to make a regulation and standard limit for the use of smut wheat in feeding of animals to reduce the more economical losses and human health. 
Iraqi J. Vet. Med. 34 ( 2 ): 9 - 14; ( 2010 ).

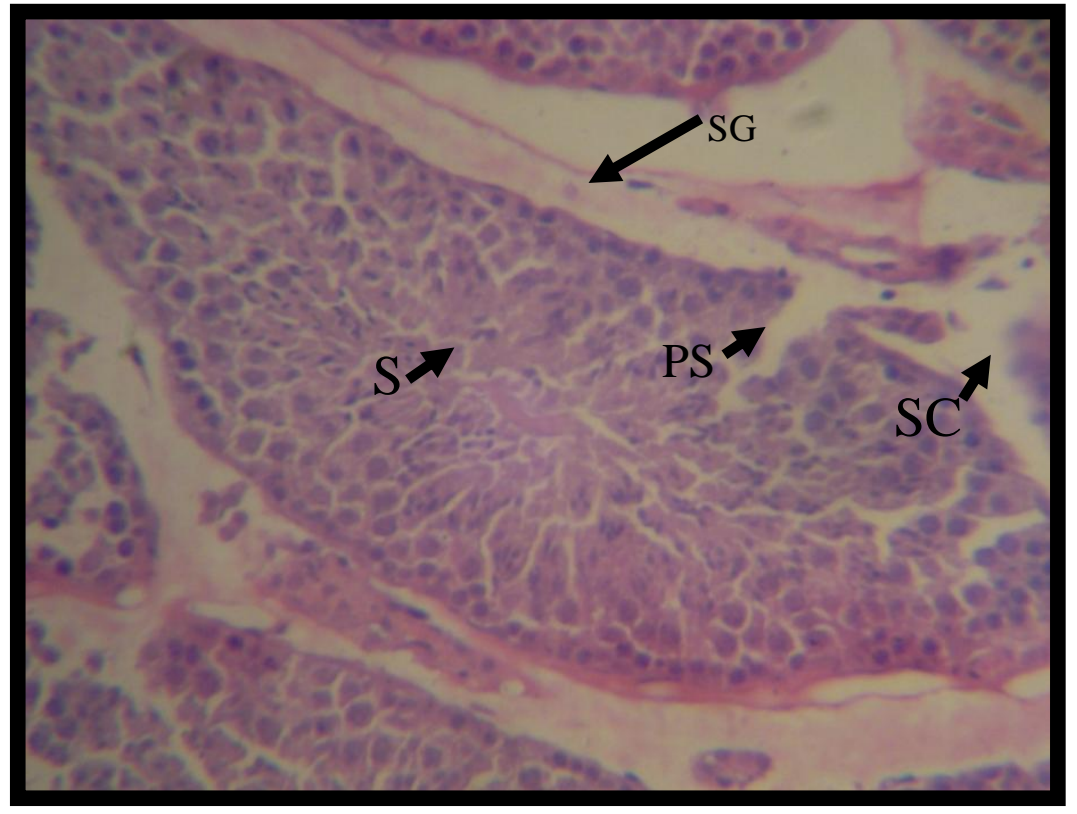

Fig. 1: Histopathological section of testis of the control male Mice shows spermatogonium (SG),primary spermatocyte (PS),Sertoli cells(SC),Spermatid (S), (H \& E 40X).

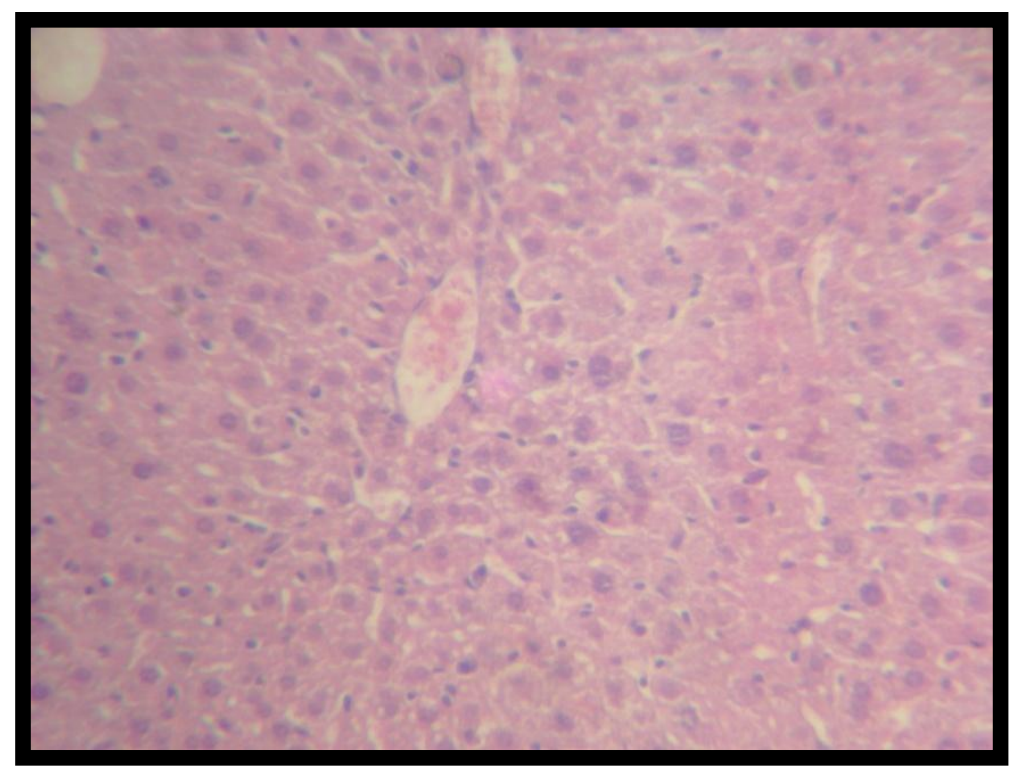

Fig. 2: Histopathological section of control male Mice show normal structure of the testis $(\mathrm{H} \& \mathrm{E} 40 \mathrm{X})$ 
Iraqi J. Vet. Med. 34 ( 2 ): 9 - 14; ( 2010 ).

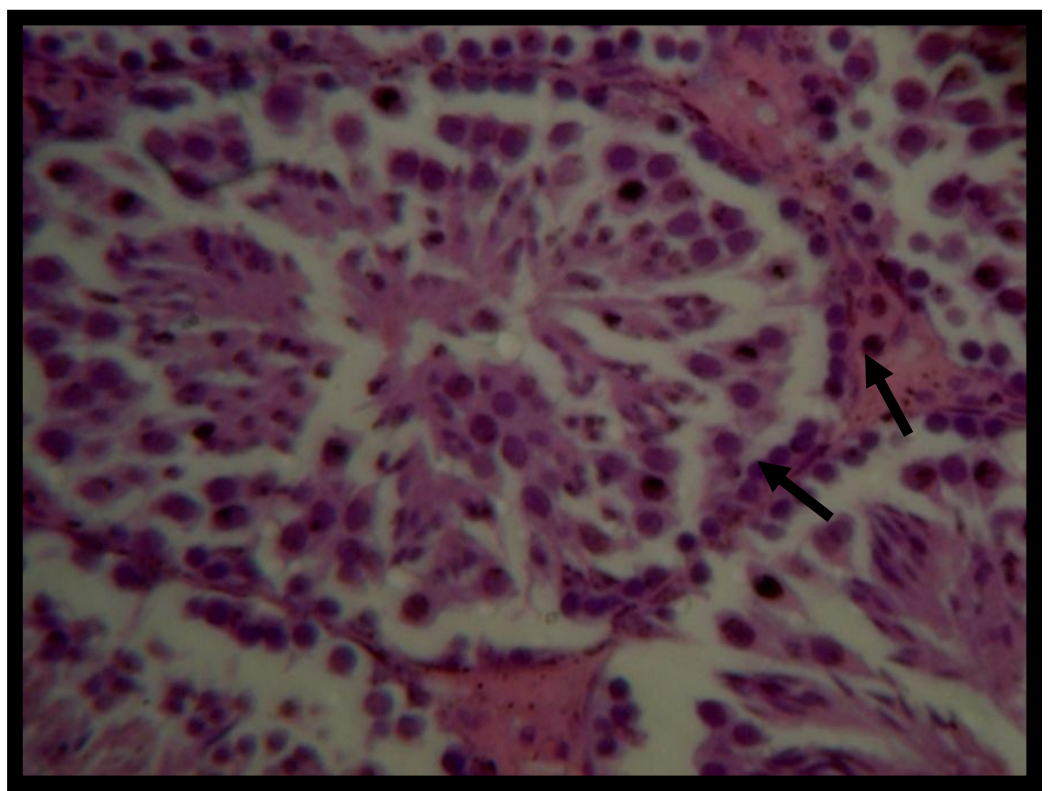

Fig. 3: Histopathological section of testis of the male Mice after 30 days post treatment with smut wheat show thickness of basement membrane of semineferous tubule due to fibroses $(\rightarrow),(\mathbf{H} \& \mathbf{E}$ stain 40X).

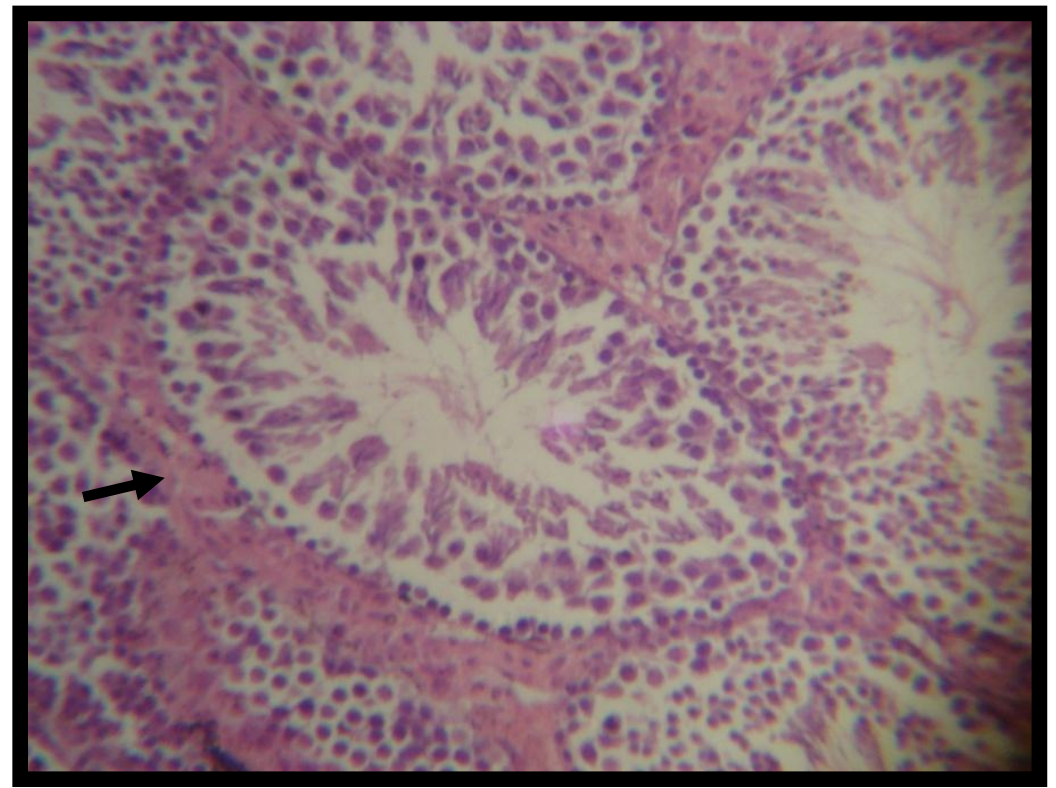

Fig. 4: Histopathological section of testis of the male Mice 30 days post treatment with smut wheat show thickness $(\rightarrow)$ of basement membrane due to fibroses (H \& $\mathrm{E}$ stain $10 \mathrm{X})$. 
Iraqi J. Vet. Med. 34 ( 2 ): 9 - 14; ( 2010 ).

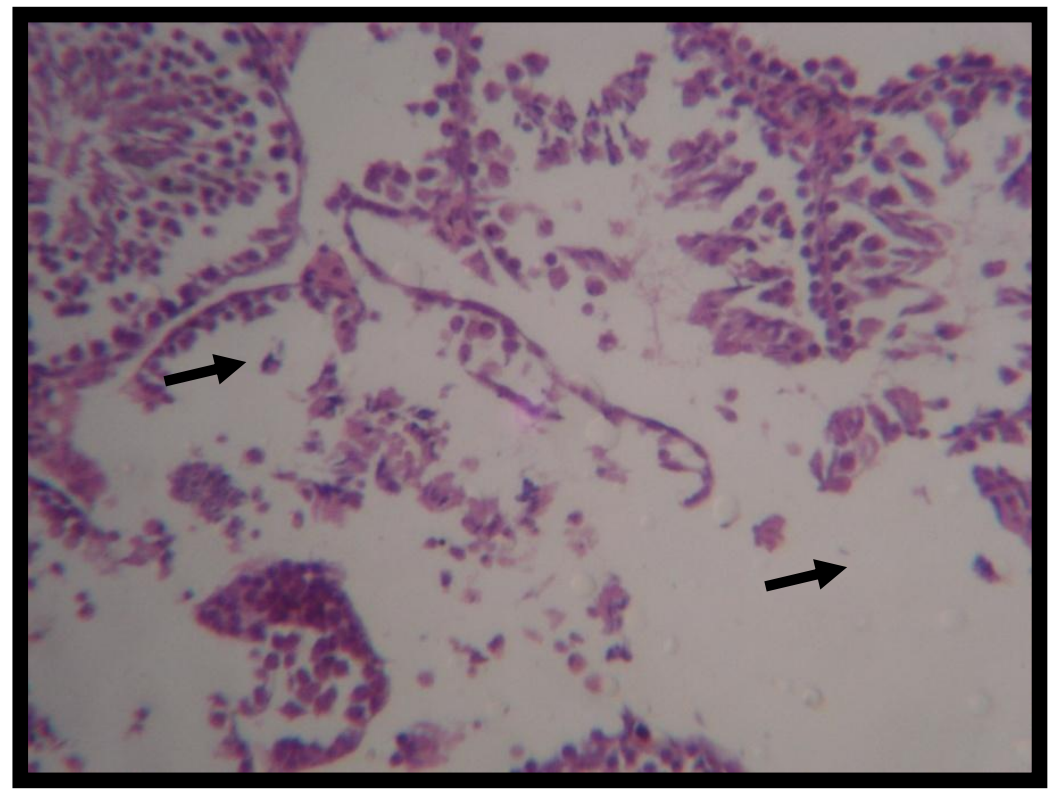

Fig. 5: Histopathological section of testis of the male Mice after 30 days post treatment with smut wheat show desquamation of sertoli cells and spermatogonium from the basement membrane of semineferous tubules as well as fibrous interstitial tissue $(\longrightarrow) \&$ in some region completely degeneration were observed, (H \& E 40X).

\section{References}

1- Hoffman JA (1982). Bunt of wheat plant disease 66: 979-986.

2- El-Bahadli AH Mohammed A Alsaidy FS Ghali and KAR AlDujaili(1978). The effect of wheat contamination by covered smut Tellitia spp on the physical, chemical and baking properties of wheat grain, flow, doug hard bread and the effect of its poisonous residue in bread. Iraqi $\mathbf{J}$ Agarie sci vol xiii.

3- Bhat RU Roe Bapue S Roy DN Malini V and Tulpule PG(1981).Toxological evaluation of Karnal Bunt Wheat in Monkeys. A report national institutes of nutrition, Hyderabad India.

4- Debre R and A(1927). Nevot. Problem of etiology of infantile Acrodynia, P. 253.

5- Basel A(1939). Annales pediatric 158: 253-308).

6- Stedman's medical spellchecker @(2006). lippincott Williams \& Wilkins.

7- Malyavin I(1926). Poisoning of cattle by fodder infected by ustilago avenae. Veterinariya Moscou t.xL., P. 45.

8- Nikol Skao O(1962). The second all union-conference on mycotoxicoses of man \& agriculture animals. J. Microbid Kiev txxix P. 64-66.

9- Luna LG(1968). Manual of Histological Staining Methods of the Armed Forces Institute of Pathology. New York, McGraw-Hill Book Company PP. $38-76$ and 222-223.

10- Bancroft JD and Stevens AA(1977). Theory and practice of histopathological techniques $1^{\text {st }}$ ed. Churchill living stons Edinburgh, London PP. 326-370. 
Iraqi J. Vet. Med. 34 ( 2 ): 9 - 14; ( 2010 ).

11- Hawthway GH Proctor NH Hughes TP(1991). Fischmann M L Practical and Hughes chemical hazards of the work place. $3^{\text {rd }}$ edition New York Nostrand Reinhold .

12- Shanshal M Al-Juboori MH Dawod Shaymaa K Abdullah Hassan H(2004). Carcinogenic polyaromatic hydrocarbons in smut wheat infected with Tolletia caries, Deutsche Lebensmittel-Rundshaw, Vol. 100 (12), PP. 505507.

13- Shanshal MR Kubba Shaima K Abhath(2004). Detection of the carcinogenic polycyclic Aromatic Hydrocarbons in Wheat Infected with Tilletia Caries, Al-Yarommk Jordan, 13(2) .

14- Harvey RG (1997).In:"Polycyclic Aromatic Hydrocarbons" Wiley-VCH, inc, New York.

15- Sotro KK Bhattcharyya and Jefcoate CR(1992). Endocrinology. Vo. 131, 3067-3076.

16-Raychoudhury SS Kubinski D(20030..Enviromental Health perspeot,June 111(1):33-8 .

17- Bhat RU Deosthale YG Roy DN Malini V and Tulpule P G(1980). Nutritional Toxilogical Evaluation of Karnal Bunt Wheat. Indian $\mathbf{J}$ of Experim Biology 18.

18- Anderson JR(1985). Muris textbook of pathology, $3^{\text {rd }}$ edition, London. 